\title{
Scenarios for the Evaluation of the Criticality Potential of High Actinide Glasses
}

by

M. J. Plodinec

Westinghouse Savannah River Company

Savannah River Site

Aiken, South Carolina 29808

DOE Contract No. DE-AC09-89SR18035

This paper was prepared in connection with work done under the above contract number with the U.S.

Department of Energy. By acceptance of this paper, the publisher and/or recipient acknowledges the U.S. Government's right to retain a nonexclusive, royalty-free license in and to any copyright covering this paper, along with the right to reproduce and to authorize others to reproduce all or part of the copyrighted paper. 


\section{DISCLAIMER}

This report was prepared as an account of work sponsored by an agency of the United States Government. Neither the United States Government nor any agency thereof, nor any of their employees, makes any warranty, express or implied, or assumes any legal liability or responsibility for the accuracy, completencss, or usefulness of any information, apparatus, product, or process disclosed, or represents that its use would not infringe privately owned rights. Reference herein to any specific commercial product, process, or service by trade name. trademark, manufacturer, or otherwise does not necessarily constitute or imply its endorsement, recommendation, or favoring by the United States Government or any agency thereof. The views and opiaions of authors expressed herein do not necessarily state or reflect those of the UnitedStates - Government or any agency thereof.

This report has been reproduced directly from the best available copy.

Available to DOE and DOE contractors from the Office of Scientific and Technical Information, P. O. Box 62, Oak Ridge, TN 37831; prices available from (615) 576-8401.

Available to the public from the National Technical Information Service, U. S. Department of Commerce, 5285 Port Royal Rd.. Springfield, VA 22161 
Keywords: Plutonium, uranium, repository, immobilization

December 4, 1995

Scenarios for the Evaluation of the Criticality Potential of High Actinide Glasses

Vitrification Working Group

Materials Disposition Immobilization Program

M. J. Plodinec (coordinator

CC: $\quad$ R. Maher, 703-A

S. Wood, 773-A

J. P. Duane, 704-F

L. M. Papouchado, 773-A

T. H. Gould, 773-41A

E. W. Holtzscheiter, 773-A

J. M. McKibben, 773-41A

E. F. Duhn, 773-A

I. K. Sullivan, 773-41A

N. H. Kuehn, 704-T

J. R. Chandler, 773-24A

W. G. Ramsey, 704-T

G. G. Wicks, 773-A

STI Records, 773-52A

\section{Off-site}

L. W. Gray, LLNL

T. Kan, LLNL

B. P. McGrail, PNNL

J. M. Perez, PNNL

J. D. Vienna, PNNL

C. W. Forsberg, ORNL

K. Elam, ORNL

D. M. Strachan, ANL

J. K. Bates, ANL

A. J. Ellison, ANL 


\section{SCENARIOS FOR THE EVALUATION OF THE CRITICALITY POTENTIAL OF HIGH ACTINIDE GLASSES}

\section{INTRODUCTION AND SUMMARY}

Vitrification is one of the leading options for immobilization of actinide-containing materials no longer needed for national defense. For these glasses to be suitable for disposal, it must be established that a significant potential for a nuclear criticality involving these glasses does not exist.

The vitrification working group within the nuclear materials disposition program has been given the responsibility for developing scenarios to be evaluated. In this report, potential bounding scenarios for disposal of high actinide glasses in a geologic setting are described. These scenarios are being provided to the Department of Energy's Office of Civilian Radioactive Waste Management (OCRWM) so that the potential for criticality can be evaluated. If the evaluation of these scenarios by OCRWM reveals a significant potential for criticality then a sensitivity analysis to numerical values should be used to determine whether more precise definitions of any parameter is warranted. It is anticipated that there will need to be extensive interactions between the working group and the personnel performing the criticality evaluations.

\section{INITIAL CONDITIONS AND ASSUMPTIONS}

The scenarios described below are all based on a common set of initial conditions and assumptions. The first is that the actinide of interest at the time of production of the glass is $\mathrm{Pu}-$ 239. $\mathrm{Pu}-239$ is mixed with nuclear poisons and melted to produce a glass in which the plutonium and any nuclear poisons added to prevent criticality are uniformly distributed. The molten glass is poured into a 304L stainless steel canister of the type used by the Defense Waste Processing Facility (DWPF), see Attachment 1. It is then welded closed. It is assumed that the glass has been formulated so that criticality of a semi-infinite array of canisters is not credible.

For all of the scenarios presented, the release of the actinides and the neutron poisons in the glass is initiated by reaction between the glass and groundwater. This presupposes that a crack has formed in any overpack placed around the DWPF canister by the repository operator, and that a crack has also formed in the DWPF canister itself. Thus, the time required before the reaction between the glass and the groundwater begins to occur is very long, most likely after the thermal pulse due to radioactive decay has begun to decay (possibly several thousand years - it is the responsibility of the OCRWM personnel to determine the time at which reaction begins). Thus, the decay of $\mathrm{Pu}-239$ to its fissile daughter, U-235, must also be taken into account.

It is assumed that the glass dissolves congruently in the groundwater. Some elements, such as boron, remain in solution, and are transported away from the canister with the groundwater. Other elements, such as Pu-239, U-235, and rare earth elements, precipitate to form sparingly soluble hydrous oxides or silicate species. It should be assumed that groundwater leaving the canister will contain these sparingly soluble species at least at their saturation concentrations. These species may also be transported out of the canister as colloidal material. The reaction between the glass and the groundwater will depend on the composition of the water (dissolved solids, $\mathrm{pH}$, redox potential), the amount of water, the composition of the glass, the surface area of the glass, and the temperature. Since the rates of reaction are relatively low, a significant portion of the $\mathrm{Pu}-239$ will have decayed to U-235 before the glass is completely reacted. Thus, again, the properties of both $\mathrm{Pu}-239$ and $\mathrm{U}-235$ must be considered. This is especially important because scoping calculations performed by the group indicate that if uranium contacts reductants in the waste package, it may precipitate in a relatively concentrated form.

Table 1 contains a matrix of initial conditions and assumptions for use in evaluating the scenarios. 
Each of these parameters, and the basis for their selection, is described below. The vitrification working group has provided only those properties specific to the glass. The working group assumes that OCRWM will use appropriate computer codes, and values of important parameters such as saturation concentrations, consistent with other OCRWM efforts. The working group can provide additional assistance to OCRWM in these efforts if necessary.

\section{Canister Contents}

The reference amount of $\mathrm{Pu}-239$ oxide in the high actinide glass is $10 \mathrm{wt} \%$. The compositions of two glasses currently being tested are given in Table 2 . Thus, each canister will initially contain $170 \mathrm{~kg}$ of $\mathrm{PuO}_{2}$ (assumed to be $\mathrm{Pu}-239$ ). Again, it should be assumed that the actinides and the neutron poisons are uniformly distributed throughout the glass. Each DWPF canister should be assumed to contain $1700 \mathrm{~kg}$ of glass in a cylinder 2 feet in diameter.

It should be assumed that the glass produced is not a monolith. The difference in the coefficients of thermal expansion of the glass and the 304L stainless steel canisters leads to cracking of HLW glass which significantly increases the surface area compared to that of a monolith. Data developed by Savannah River Technology Center indicates that not all of this additional surface area is involved in the dissolution process, at least initially. However, as the glass corrosion process proceeds, more of the internal surface area is likely to be exposed. For this reason, two surface areas are provided: $5 \mathrm{~m}^{2}$, which corresponds to the surface area of a HLW glass monolith; and $100 \mathrm{~m}^{2}$, which corresponds to the maximum surface area which has been reported for HLW canisters.

Once the canister is breached, and water enters, the amount of water in direct contact with the glass will be limited to that within the canister. For DWPF glass, the volume of void space above the glass in the canister is nominally $165 \mathrm{~L}$. However, some of these high actinide glasses are at least twice as dense as DWPF glass. For this reason, two volumes of canister void space (assumed to equal the volume of water in direct contact with the glass) have been provided $-165 \mathrm{~L}$ and $330 \mathrm{~L}$.

\section{Glass Dissolution Rates}

As noted above, the rate of glass dissolution will depend on the glass composition, the surface area of the glass, the groundwater composition, the volume of water in contact with the glass, and the temperature. For natural groundwaters of the type expected in an underground repository (e.g., at Yucca Mountain), the glass dissolution rates in deionized water will bound those in groundwater. The rates recommended for use in this document are primarily based on experiments performed at $90^{\circ} \mathrm{C}$. Thus, their use presupposes that the thermal pulse in the repository has passed. They should overestimate the rate of glass-groundwater reaction at lower temperatures.

Two values are give in Table 1 for glass dissolution rates -0.0001 and $0.1 \mathrm{~g} /\left(\mathrm{m}^{2} \cdot \mathrm{d}\right)$. The lower value is $1 \%$ of that found for typical DWPF glasses, but has been measured for the first composition in Table 2 (containing actinide simulants). 1 The upper value corresponds to a rate which might be seen for a typical DWPF glass in a 28 day MCC-1 type test, and thus is probably an overestimate of the long-term dissolution rate.

\section{SCENARIOS}

The high actinide glass will contain neutron poisons to ensure safety during production and interim storage. These poisons, which are uniformly distributed in the glass with the actinides, may be either soluble or insoluble in groundwater. Thus, the key question to be answered for safe disposal is whether a scenario exists in which the plutonium and the neutron poisons are separated as a result of reaction of the glass with groundwater resulting in a criticality event. Criticality can 
only occur if the scenario leads to the accumulation of plutonium to critical levels, in a geometry favorable for criticality. If such a scenario is credible, then a means to prevent this scenario from occurring must be found, such as changing the glass composition or the waste package design.

In the following scenarios, processes which will separate the actinides from neutron poisons in the glass are discussed. The numerical values assumed for the various processes are believed to be generally biased toward those more favorable for causing a criticality. However, some of these parameters are not precisely known. If, after evaluation, one of these scenarios has a significant criticality potential, an analysis of the sensitivity of the criticality to the numerical values should be used to determine whether more precise definitions of numerical values is warranted.

Alternatively, the vitrification working group may elect to refine the scenario so that it is not as conservative.

In the scenarios which follow, it is assumed that the species of interest are the fissile materials (Pu239 and its daughter, U-235), and the neutron poisons (boron and the rare earth elements). It is further assumed that boron from the dissolving glass is soluble, and transported away from the glass with the groundwater. The scenarios are differentiated by the assumed behavior of plutonium, uranium and the rare earth elements.

\section{$\underline{\text { Scenario } 1}$}

In the first scenario, it is assumed that separation of actinides and rare earth poisons occurs only because of the difference in solubilities. The actinides and rare earth elements are transported away from the canister in groundwater which is saturated with each of them. Based on the solubilities of plutonium and the rare earth hydrous oxides, the proportion of each of these in the groundwater will be different from that in the glass, thus providing a mechanism for separation. Since the solubility of plutonium will differ from that of uranium, decay during transport also needs to be considered. As the actinides are transported away from the canister, dilution and dispersion effects must be considered. The potential for a criticality event should be evaluated for both the actinides transported away from the canister, as well that portion which remains behind in the canister.

\section{$\underline{\text { Scenario } 2}$}

This scenario adds an additional separation mechanism to the first scenario. Once the saturated groundwater leaves the canister, it will experience a further "chromatographic" effect due to differential sorption of the rare earths and the actinides. This may affect the potential for criticality of actinides which are transported away from the canister, but should not affect those remaining behind in the canister. As the actinides are transported away from the canister, dilution and dispersion effects must also be considered.

\section{$\underline{\text { Scenario } 3}$}

In this scenario, the actinide is transported away from the canister as a colloid. Thus, the groundwater leaving the canister is both saturated with actinide and rare earths as well as containing the rest of the actinide as a colloidal sol. The rare earths are present in the groundwater only at their saturation concentrations. In this case, there is no need to evaluate the criticality potential for material remaining in the canister, because there is no enrichment of actinide. As the actinides are transported away from the canister, dilution and dispersion effects must again be considered.

\section{$\underline{\text { Scenario } 4}$}

In this scenario, the rare earth is transported away from the canister as a colloid. Thus, the 
groundwater leaving the canister is both saturated with actinide and rare earths as well as containing the rest of the rare earth released from the glass as a colloidal sol. The rare earths are present in the groundwater only at their saturation concentrations. In this case, evaluation of the criticality potential of actinides remaining in the canister is necessary, because the amount of poison remaining is significantly depleted.

TABLE 1

INITIAL CONDITIONS FOR CRITICALITY SCENARIOS

\section{Condition}

Plutonium loading of glass

Glass composition

Glass content of canister

Glass surface area

Glass dissolution rate

\section{$\underline{\text { Value(s) }}$}

$10 \mathrm{wt} \%$

See Table 2

$1700 \mathrm{~kg}$

5 or $100 \mathrm{~m} 2$

$0.0001 \mathrm{~g}$ glass $/\left(\mathrm{m}^{2 \cdot d}\right)$ or $0.1 \mathrm{~g} \operatorname{glass} /\left(\mathrm{m}^{2} \cdot \mathrm{d}\right)$

TABLE 2

COMPOSITIONS OF HIGH ACTINIDE GLASS

GLASS 1

COMPONENT

$\mathrm{SiO}_{2}$

$\mathrm{B}_{2} \mathrm{O}_{3}$

$\mathrm{BaO}$

$\mathrm{Al}_{2} \mathrm{O}_{3}$

$\mathrm{ZrO}_{2}$

$\mathrm{PbO}$

$\mathrm{La}_{2} \mathrm{O}_{3}$

$\mathrm{Sm}_{2} \mathrm{O}_{3}$

$\mathrm{PuO}_{2}$

COMPONENT

$\mathrm{SiO}_{2}$

$\mathrm{B}_{2} \mathrm{O}_{3}$

$\mathrm{Li}_{2} \mathrm{O}$

$\mathrm{Na}_{2} \mathrm{O}$

$\mathrm{K}_{2} \mathrm{O}$

$\mathrm{Cs}_{2} \mathrm{O}$

$\mathrm{Al}_{2} \mathrm{O}_{3}$

$\mathrm{Gd}_{2} \mathrm{O}_{3}$

$\mathrm{ZrO}_{2}$

$\mathrm{SnO}_{2}$

$\mathrm{TiO}_{2}$

$\mathrm{PuO}_{2}$
AMOUNT (wt \%)

31.4

5.5

3.2

9.9

0.2

13.6

8.5

17.7

10.0

GLASS 2

AMOUNT (wt \%)

44.6

11.7

3.9

8.8

5.0

0.9

2.2

3.2

5.0

2.6

2.0

10.0 
Figure 1. DWPF canister dimensions 
Figure 1. DWPF canister dimensions

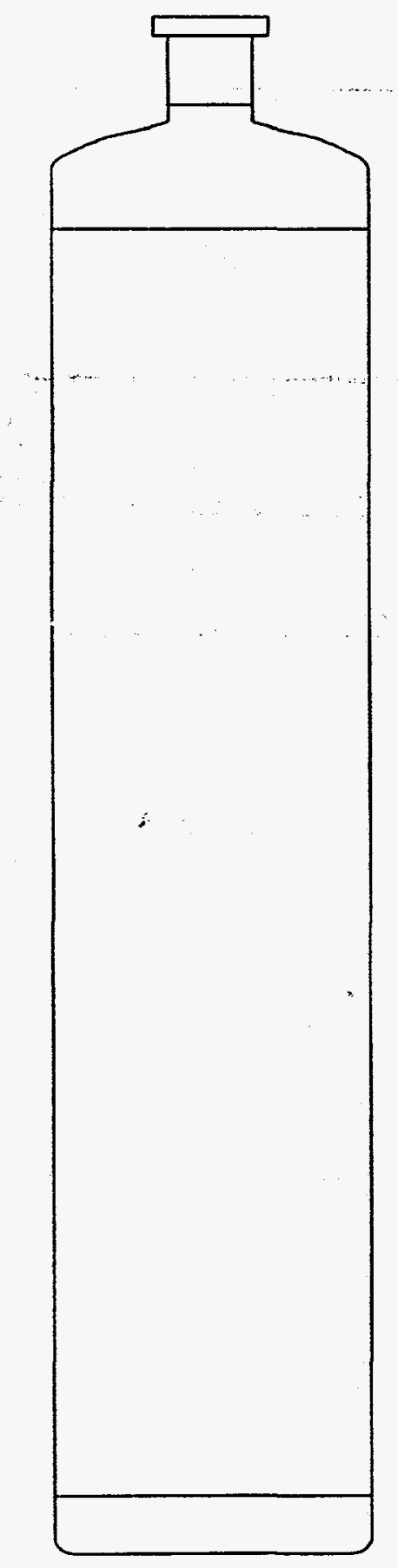

Overall length

Top end diameter

Top diameter

Middle diameter

Bottom diameter

Bottom end diameter

Flange tilt from horizontal

Upper head mis-match

Lower head mis-match

Bow (middle)

$\begin{array}{cc}\text { Average } & \text { Std.Dev. } \\ 117.98 \mathrm{in} & 0.03 \mathrm{in} \\ (299.67 \mathrm{~cm}) & (0.08 \mathrm{~cm}) \\ & \\ 23.97 \mathrm{in} & 0.02 \mathrm{in} \\ (60.88 \mathrm{~cm}) & (0.051 \mathrm{~cm}) \\ 24.02 \mathrm{in} & 0.02 \mathrm{in} \\ (61.01 \mathrm{~cm}) & (0.05 \mathrm{~cm}) \\ 24.04 \mathrm{in} & 0.03 \mathrm{in} \\ (61.06 \mathrm{~cm}) & (0.08 \mathrm{~cm}) \\ 24.04 \mathrm{in} & 0.02 \mathrm{in} \\ (61.06 \mathrm{~cm}) & (0.05 \mathrm{~cm}) \\ 24.02 \mathrm{in} & 0.03 \mathrm{in} \\ (61.01 \mathrm{~cm}) & (0.08 \mathrm{~cm}) \\ & \end{array}$

$$
\begin{array}{ll}
0.31^{\circ} & 0.19^{\circ}
\end{array}
$$

-0.07 in $\quad 0.09$ in $(-0.178 \mathrm{~cm}) \quad(0.23 \mathrm{~cm})$
-0.03 in $\quad 0.02$ in $(-0.08 \mathrm{~cm}) \quad(0.05 \mathrm{~cm})$

0.007 in $\quad 0.080$ in $(0.02 \mathrm{~cm}) \quad(0.20 \mathrm{~cm})$ maximum bow (middle) --0.141 in $(-0.358 \mathrm{~cm})$

Bow (top)

$\begin{array}{cc}-0.008 \text { in } & 0.09 \text { in } \\ (-0.020 \mathrm{~cm}) & (0.22 \mathrm{~cm})\end{array}$
maximum bow (top) -0.172 in $(0.437 \mathrm{~cm})$

Change in diameter after filling*: Top end diameter

Maximum Top diameter

Middle diameter

Bottom diameter

Bottom end diameter

* measurements from six canisters 


\section{REFERENCES}

1. M. J. Plodinec, W. G. Ramsey, "Glass Consistency and Glass Performance," Spectrum '94, Proceedings of the American Nuclear Society's Topical Meeting on Nuclear and Hazardous Waste Management, 1490-95 (1994). 